\title{
Study of Factors Affecting the Entrepreneurship Behavior of Returned Migrants Using Binary Logistic Regression Model
}

Madhav Kumar Bhusal ${ }^{*}$ and Hari Prasad Pandey²

Submitted: 22 July 2019; Accepted: 28 August 2019

Published online: 16 September 2019

DOI: https://doi.org// 0.3 I 26/njs.v3i0.25578

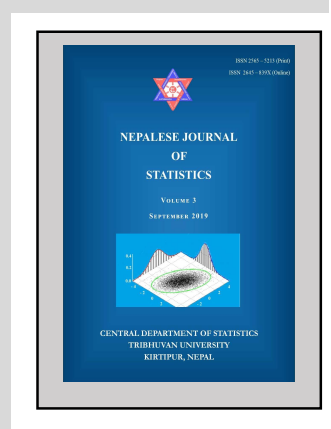

\begin{abstract}
Background: Entrepreneurship or business ownership is a significant source of employment and economic growth. Many studies conducted by different researchers have shown that increase in entrepreneurial activities helps to reduce unemployment. Thousands of Nepalese youths exodus for foreign migration every year for employments due to lack of adequate working environment in Nepal. In this context, identification of significant factors influencing the entrepreneurship behavior of returned migrants could be useful for planner, decision makers, and other concerned authorities.
\end{abstract}

Objective: To explore the entrepreneurship status of returned migrants and to ascertain the factors influencing the entrepreneurship behavior of returned migrants.

Materials and Methods: This study was based on primary data of 393 returned migrants collected through convenience sampling in Sarawal Rural Municipality of Parasi district, Nepal. People who stayed abroad at least one year and returned during 2010 to 2017 were included in the study. On the basis of Industrial Enterprise Act, 2016a, Nepal, a person who has invested Nepalese rupees five lakh or more in business besides housing and land is considered as an entrepreneur. The response variable is entrepreneurship status and it is defined according to the aforementioned act. Both quantitative and categorical variables were used as predictor variables. Factors associated with entrepreneurship behavior were extracted using Chi-square test and binary logistic regression model.

Results: Out of sample of 393 returned migrants, 137 (34.9\%) were entrepreneur and rest $256(65.1 \%)$ were non-entrepreneur. Results showed that for main occupation of household head odds ratio $(O R)=4.008 \&$ confidence interval $(\mathrm{Cl})=2.396$ to 6.703 . Similarly, for educational status of returned migrants $\mathrm{OR}=2.650 \& \mathrm{Cl}=1.599$ to 4.392 . For the covariate skills learnt at abroad $\mathrm{OR}=2.750 \& \mathrm{Cl}=1.654$ to 4.573 .

Conclusion: The study revealed that majority of returned migrants were non-entrepreneur. The factors 'main occupation of household head', 'educational status of returned migrant', 'remittance received at home per year' and 'skills learnt abroad' are the major determinants 
behind the entrepreneurship behavior of returned migrants. It is suggested that higher education and adequate skills should be taken before departing from home country so that the migrants can earn more money which will help to start their own businesses once they get back to their home country.

Keywords: Binary logistic regression, entrepreneur, entrepreneurship behavior, foreign migration, returned migrants, Sarawal rural municipality.

Address correspondence to the author: Central Department of Statistics, Tribhuvan University, Kirtipur, Kathmandu, Nepal.

Email: madhavkbhusal@gmail.com(Corresponding author) ${ }^{\prime *}$; Universal Sustainable Development Consultancy (USDC) Pvt. Ltd., Chandol, Kathmandu, Nepal.

Email: harrypandey0102@gmail.com²

\section{INTRODUCTION}

According to the Oxford dictionary, entrepreneur is defined as a person who sets up a business or businesses taking on financial risks in the hope of profit. Entrepreneurship is the process of defining, lunching and running a new business which is often initially a small business. Thomson and Bolton (2013) defined entrepreneur is someone who starts a business, arranges ideas and takes risks in order to make profit. K.C. (2004) stated that an entrepreneur assembles, coordinates and directs various factors of production namely land, labor, capital and other materials. An entrepreneur could be a trader, a technician, social worker, businessman, educationalist etc. The Department of Industry [Dol] (2016), Nepal has defined entrepreneurs are those person who have invested five lakhs or more in business besides housing and land.

It is a bitter reality that large number of Nepalese youths have been departing for foreign employment due to abject scenario of employment, poor development of industrial sectors, lack of adequate business environment and so on till the date. Remittance is one of the significant contributor to Gross Domestic Product (GDP) in Nepal in the recent years which was 29.6 percent in the fiscal year 2015/ 16 (Nepal Rastra Bank, 2015/ 16). Hass (2010) reported an optimistic opinion about foreign migration that it helps to reduce poverty as the people migrates from low income to high income economy. Khadria (2006) posited that the various studies on temporary international migration have indicated the win-win situation for both home and host countries. Usually the people migrated to the developed countries not only to earn money but also they acquired new skills, which is a lifelong assets to run their own business or to be an entrepreneur if they wish.

Study conducted by the various researchers have observed that remittance have significant role in reducing poverty and inequality in Nepal (Lokshin, Bontch-Osmolovski \& Glinskaya, 2010; 
Acharya \& Leon- Gonzalez, 2013). Most of the studies carried out regarding use of remittance has pointed that it is mostly used for consumption rather than investment in productive sectors. Chami, Fullenkamp and Jahjan (2005) have mentioned that the use of remittance of various countries shows that major segment of the remittance is spent on purchase status of oriented goods like housing, land, ornaments which are not productive to the economy whereas only the smaller portion is allocated for investment on business. According to Dorantes and Pozo (2006); Mahmood (1991) most of the remittance is used for basic consumptions, health care and education of family members, purchase of land, building houses, repayment of loans. McCormic and Wahba (200I) has conducted a study in Egypt to explore the association between foreign employment, saving and entrepreneurial activities among 1526 returned migrants. By applying a Probit model to study the factor affecting entrepreneurial activities among returned migrant, they found that amount of money saving abroad and length of stay abroad have positive correlation to entrepreneurship after return.

\section{MATERIALS AND METHODS}

\section{Data and study area}

This study is based on the cross-sectional research design. Primary data was collected using interview schedule developed through in-depth reviews of literature. The study was conducted at Sarawal Rural Municipality of Parasi district Nepal. The foreign migrants who had stayed at least one year at abroad and returned Nepal between 2010 and 2017 were considered as the population of the study. A sample of 393 returned migrants were conveniently taken as the unit of analysis for the study.

\section{Variables}

The response variable of this study is entrepreneurship behavior of returned migrants. It is dichotomous in nature. The returned migrants were classified as an entrepreneur or nonentrepreneur based on the Industrial Enterprise Act 2016a, Nepal. By reviewing the various literatures different continuous and categorical variables are selected as an explanatory variables. The explanatory variables included in the study are age, caste/ethnicity, main occupation of household head, family size, educational status, skills learnt at abroad, remittance sent per year and length of stay at abroad.

\section{Data analysis}

The entrepreneurship status of returned migrants is assessed by the descriptive analysis of the collected information. The significant factors of entrepreneurship behavior were identified using Chi-square test and binary logistic regression model. Finally a binary logistic regression model was developed to establish the relationship between entrepreneurial status and the significant factors affecting it. The logistic regression works in a similar manner as linear regression for a binomial response variable. 
Let

$$
\begin{aligned}
Y_{i}=\quad \text { I, Non-entrepreneur } \\
\text { 0, Entrepreneur }
\end{aligned}
$$

The logistic regression model can be extended with number of explanatory variables $\left(X_{i}\right)$. The model for $\pi_{i}=P\left(Y_{i}=1\right)$ and $1-\pi_{i}=P\left(Y_{i}=0\right)$ for $m$ explanatory variables $X_{1}, X_{2}, \ldots \ldots, X_{m}$ is given as;

$$
\pi_{i}=\frac{1}{1+e^{-\left(\beta_{0}+\sum_{j=1}^{m} \beta_{j} X_{j}\right)}}
$$

and

$$
1-\pi_{i}=\frac{e^{-\left(\beta_{0}+\sum_{j=1}^{m} \beta_{j} X_{j}\right)}}{1+e^{-\left(\beta_{0}+\sum_{j=1}^{m} \beta_{j} X_{j}\right)}}
$$

The relation (I) and (2) implies that

$$
\frac{\pi_{i}}{1-\pi_{i}}=e^{\left(\beta_{0}+\sum_{j=1}^{m} \beta_{j} X_{j}\right)}
$$

The logistic regression analysis model the chance of an outcome based on individual characteristics. The chance is a ratio, the model for the logarithm of the chance is given by;

$$
\ln \left(\frac{\pi_{i}}{1-\pi_{i}}\right)=\beta_{0}+\sum_{j=1}^{m} \beta_{j} X_{j}
$$

where $\pi_{i}$ indicates the probability of an event, $0 \leq \pi_{i} \leq 1, X_{j}$ are explanatory variables with $i=1,2, \ldots, n$ and $j=1,2, \ldots, m . \beta_{j}$ are the regression coefficients associated with the reference groups. The reference group, represented by $\beta_{0}$, is consisted by those individuals presenting the reference level of each and every variable $X_{1}, X_{2}, \ldots \ldots, X_{m}$ (Sperandei, 2013).

\section{Model adequacy test}

Hosmer and Lemeshow test for goodness of fit is applied to assess the overall fit of the model. For this test Pearson Chi-square with $\mathrm{p}$-value greater than 0.05 is considered to make conclusion about the goodness of fit of the model. The collinearity between the explanatory variables is ensured by computing Variance Inflation Factor (VIF). The Negelerke Pseudo R-square is applied to measure the amount of variation on outcome variable explained by the predictor variables.

\section{RESULTS}

\section{Descriptive analysis}

Table I displays the entrepreneurial status of returned migrants. Out of 393 returned migrants, 137 (34.9\%) were entrepreneur and 256 (65.1\%) were non-entrepreneur. The person who have invested five lakhs or more in business besides housing and land to run his/ her business was considered as an entrepreneur. 
Table I. Entrepreneurial status of returned migrants.

\begin{tabular}{lcc}
\hline Entrepreneurship Status & No. of returned migrants & Percent \\
\hline Entrepreneur & 137 & 34.9 \\
\hline Non-entrepreneur & 256 & 65.1 \\
\hline Total & 393 & 100.0 \\
\hline
\end{tabular}

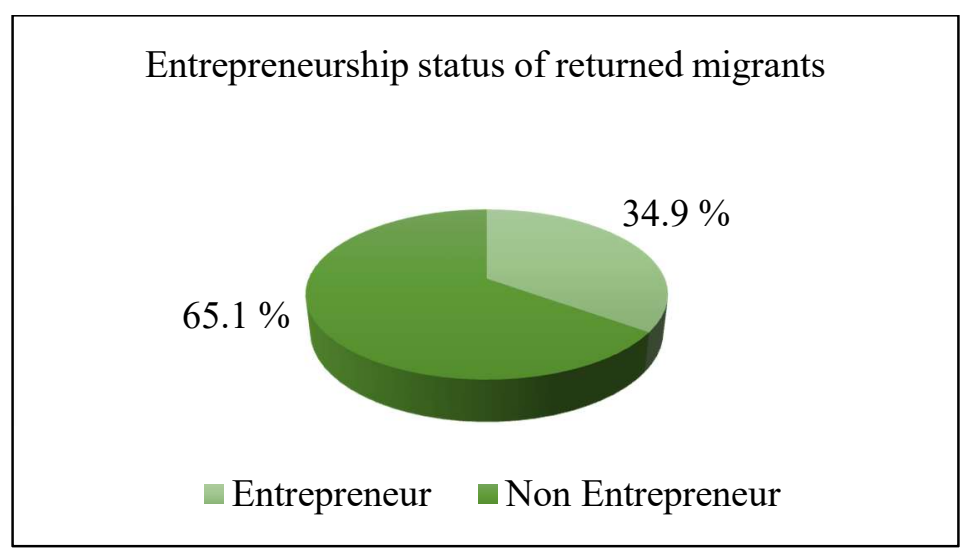

Fig. I. Entrepreneurship status.

Table 2 shows the frequency distribution of returned migrants and their entrepreneurial status on the basis of categorical variables in the study. Out of 387 returned male migrants, 135 (34.9\%) were entrepreneur and 252 (65.1\%) were non-entrepreneur.

Among the 6 female migrants only 2 (33.2\%) were entrepreneur and 4 (66.7\%) were nonentrepreneur. Among 28I returned Madhesi migrants, 85 (30.2\%) were entrepreneur and 196 (69.8\%) were non-entrepreneur. Among 70 returned migrants who were from Brahmin/ Chhetri community, 35 (50\%) were entrepreneur and next 35 (50\%) were non-entrepreneur. Most of the returned migrants were between age group 21 to 30 and among them 52 (27.7\%) and 136 (72.3\%) were entrepreneur and non-entrepreneur respectively. Majority of the household head of returned migrants 267 out of 393 involve in agriculture as their main occupation. Among these 68 (25.5\%) returned migrants were entrepreneur and rest 199 (74.5\%) were non-entrepreneur. Almost equal number of returned migrants have family size between 0 to 5 and 6 to 10 respectively. Further, most of the returned migrants 382 out of 393 have received education secondary level and below. However the entrepreneurial status is seems to be high in those returned migrants who have received secondary level and above. 357 out of 393 were married and 109 among the total 393 have learnt some skills while they were at abroad. Out of 109 returned migrants who have learnt any kind of skills at abroad 60 (55\%) were entrepreneur and 49 (45\%) were nonentrepreneur. 
Table 2. Bivariate analysis of entrepreneurial status of returned migrants with covariates and some demographic variables.

\begin{tabular}{|c|c|c|c|c|}
\hline Variables & Levels & Entrepreneur & Non-Entrepreneur & Total \\
\hline \multirow{2}{*}{ Gender } & Male & 135 (34.9\%) & $252(65.1 \%)$ & 387 \\
\hline & Female & $2(33.3)$ & $4(66.7)$ & 6 \\
\hline \multirow{3}{*}{ Marital status } & Married & $131(36.7)$ & $226(63.3)$ & 357 \\
\hline & Unmarried & $6(17.6)$ & $28(82.4)$ & 34 \\
\hline & $\begin{array}{l}\text { Divorced } \\
\text { \&Widowed }\end{array}$ & $0(0.00)$ & $2(100.0)$ & 2 \\
\hline \multirow{5}{*}{ Caste/ Ethnicity } & Madhesi & $85(30.2)$ & $196(69.8)$ & 281 \\
\hline & Brahmin/ Chhetri & $35(50)$ & $35(50)$ & 70 \\
\hline & Muslim & $14(46.7)$ & $16(53.3)$ & 30 \\
\hline & Others & $3(25)$ & $9(75)$ & 12 \\
\hline & \multicolumn{4}{|c|}{ Chi-square $(p$-value $)=12.052(0.007)$} \\
\hline \multirow{4}{*}{ Age-group } & 21 to 30 & $52(27.7)$ & $136(72.3)$ & 188 \\
\hline & 31 to 40 & $62(40)$ & $93(60)$ & 155 \\
\hline & More than 40 & $23(46)$ & $27(54)$ & 50 \\
\hline & \multicolumn{4}{|c|}{ Chi-square $(p$-value $)=8.824(0.012)$} \\
\hline \multirow{3}{*}{$\begin{array}{l}\text { Main occupation of household } \\
\text { head }\end{array}$} & Agriculture & $68(25.5)$ & $199(74.5)$ & 267 \\
\hline & Non-agriculture & $69(54.8)$ & $57(45.2)$ & 126 \\
\hline & \multicolumn{4}{|c|}{ Chi-square $(p-$ value $)=32.349(<0.0001)$} \\
\hline \multirow{4}{*}{$\begin{array}{l}\text { Family size of the returned } \\
\text { migrants }\end{array}$} & 0 to 5 & $61(36.3)$ & $107(63.7)$ & 168 \\
\hline & 6 to 10 & $57(33.7)$ & $112(66.3)$ & 169 \\
\hline & More than 10 & $19(33.9)$ & $37(66.1)$ & 56 \\
\hline & \multicolumn{4}{|c|}{ Chi-square $(p$-value $)=0.272(0.873)$} \\
\hline \multirow{4}{*}{$\begin{array}{l}\text { Educational status of returned } \\
\text { migrants }\end{array}$} & Primary (I to 8) & $45(24.3)$ & $140(75.7)$ & 185 \\
\hline & $\begin{array}{l}\text { Secondary (9 to } \\
12 \text { ) }\end{array}$ & $84(42.6)$ & II $3(57.4)$ & 197 \\
\hline & Above secondary & 8 (72.7) & $3(27.3)$ & II \\
\hline & \multicolumn{4}{|c|}{ Chi-square $(p$-value $)=17.087(<0.000 I)$} \\
\hline \multirow{4}{*}{$\begin{array}{l}\text { Remittance received at home } \\
\text { per year (in lakhs Rs.) }\end{array}$} & Less than 2 & $8(18.2)$ & $36(81.8)$ & 44 \\
\hline & 2 to 5 & $87(30.2)$ & $201(69.8)$ & 288 \\
\hline & More than 5 & $42(68.9)$ & $19(31.1)$ & 61 \\
\hline & \multicolumn{4}{|c|}{ Chi-square $(p$-value $)=39.174(<0.0001)$} \\
\hline \multirow{3}{*}{ Skills learnt at abroad } & Yes & $60(55)$ & $49(45)$ & 109 \\
\hline & No & $77(27.1)$ & $207(72.9)$ & 284 \\
\hline & \multicolumn{4}{|c|}{ Chi-square $(p$-value $)=27.066(<0.000 \mathrm{I})$} \\
\hline \multirow{5}{*}{$\begin{array}{l}\text { Length of stay abroad (in } \\
\text { years) }\end{array}$} & Less than 2 & $14(18.2)$ & $63(81.8)$ & 77 \\
\hline & 2 to 4 & $38(27.7)$ & $99(72.3)$ & 137 \\
\hline & 4 to 6 & $40(44.9)$ & $49(55.1)$ & 89 \\
\hline & More than 6 & $45(50)$ & $45(50)$ & 90 \\
\hline & \multicolumn{4}{|c|}{ Chi-square $(p$-value $)=25.563(<0.000 \mathrm{I})$} \\
\hline
\end{tabular}


Table 3. Frequency of returned migrants from which country they returned to Nepal.

\begin{tabular}{lcc}
\hline Country & No. of returned migrants & Percent \\
\hline Malaysia & 148 & 37.7 \\
\hline Saudi Arabia & 75 & 19.1 \\
\hline Qatar & 67 & 17 \\
\hline UAE & 58 & 14.8 \\
\hline India & 15 & 3.8 \\
\hline Kuwait & 12 & 3.1 \\
\hline South Korea & 7 & 1.8 \\
\hline Europe & 5 & 1.3 \\
\hline Japan & 4 & 1.0 \\
\hline Others (USA, China) & 2 & 0.5 \\
\hline Total & 393 & 100.0 \\
\hline
\end{tabular}

Table 3 shows the frequency distribution of the returned migrants about from which country they returned to Nepal during the period specified by the study. Among 393 returned migrants most 148 (37.7\%) were from Malaysia, 75 (19.1\%) were from Saudi Arabia followed by 67 (17\%) were from Qatar and 58 (14.8\%) were from UAE. The remaining returned migrants 45 (1 I.45\%) were from India, Kuwait, South Korea, Europe, Japan, USA and China.

Table 4(a). Descriptions of continuous variables.

\begin{tabular}{lccccc}
\hline Variables & $\mathrm{N}$ & Min. & Max. & Mean & SD \\
& & & & & \\
\hline Remittance sent per year (in NRS) & 393 & 100,000 & 180,0000 & $382,101.78$ & $249,019.40$ \\
\hline Length of stay at abroad (in years) & 393 & $\mathrm{I}$ & 25 & 5.04 & 3.53 \\
\hline
\end{tabular}

Table 4(b). Descriptions of continuous variables.

\begin{tabular}{|c|c|c|c|c|c|}
\hline \multirow[b]{2}{*}{ Variables } & \multirow[b]{2}{*}{$\mathrm{N}$} & \multirow[b]{2}{*}{ Median } & \multirow[b]{2}{*}{ Mode } & \multicolumn{2}{|c|}{ Quartiles } \\
\hline & & & & $\begin{array}{l}\text { Lower } \\
\text { quartile }\end{array}$ & $\begin{array}{l}\text { Upper } \\
\text { quartile }\end{array}$ \\
\hline Remittance sent per year (in NRS) & 393 & 336,000 & 360,000 & 240,000 & 420,000 \\
\hline Length of stay at abroad (in years) & 393 & 4 & 3 & 3 & 6 \\
\hline
\end{tabular}

Table 4 (a \& b) depicts the summary statistics of the continuous variable used in the study. The average remittance sent per year by the returned migrant when they were at abroad is Rs. $382,101.78$ with range of Rs. 100,000 to Rs. 180,0000 . From Table 4 it is also seen that the returned 
migrants had stayed at abroad on an average 5.04 years with minimum one years to maximum 25 years.

\section{Inferential analysis}

Chi-square test was performed to identify the covariate that has significant relationship with entrepreneurial status. The bivariate analysis as shown in Table 2 revealed that the factor 'age of migrant' and 'family size' were insignificant whereas the factors, 'caste/ethnicity', 'main occupation of household head', 'educational status of returned migrants', 'remittance received at home per year', 'skills learnt at abroad', and 'length of stay at abroad' were found to have significant relationship with 'entrepreneurial status' of the returned migrants. The $5 \%$ level of significance was used for the statistical significant of the test.

After screening the significant factor that affect the entrepreneurial behavior of returned migrants, further to develop the final model using binary logistic regression, the stepwise regression method was applied. Both the forward and backward likelihood ratio method provided the same significant covariates. The factors were 'main occupation of household head', 'educational status of returned migrants', 'total remittance received at home per year, and 'skills learnt at abroad'. Further, the binary logistic regression was performed to ascertain the effect of thus obtained significant predictor variables on 'entrepreneurial status' of returned migrants. Before performing the binary logistic regression, the absence of multicollinearity between the covariates was assessed with variation inflation factor (VIF). All the factors which were selected in stepwise regression were also appeared to be significant ( $p$-value $<0.00 \mathrm{I}$ ) in multiple regression model at 0.05 level of significance.

The overall fitting of binary logistic regression model was statistically significant, $\chi^{2}=94.27, \mathrm{P}$ $<0.001$. The fitted model as shown in Table 5 revealed that the odds of being non-entrepreneur of returned migrants from those household in which agriculture is the major occupation of household head is about four times more as compared to those returnees having non-agriculture as the major occupation of household head. Similarly, the returned migrants who have attained the primary level education were nearly three times more likely to be non-entrepreneur than those returned migrants who have attained higher than primary level education. Talking with regard to the remittance received per year (in Rs.), the returned migrant who had sent remittance less than 2 lakhs per year, the odds of being non-entrepreneur is about six times more than those who had sent remittance more than 5 lakhs per year. Likewise, the odds of being non-entrepreneur among returned migrants who had sent remittance 2 to 5 lakhs per year is about three times more as compared to those who had sent remittance more than 5 lakhs per year. Also, the odds of being non-entrepreneur is about three times more among returned migrants who have not learnt skills on the comparison to those who have acquired some kinds of skills at abroad. 
Table 5. Fitted model for explaining the entrepreneurial status of returned migrants, $\mathrm{N}=393$.

\begin{tabular}{|c|c|c|c|c|c|c|}
\hline \multirow[b]{2}{*}{ Explanatory Variables } & \multirow[b]{2}{*}{ B } & \multirow[b]{2}{*}{ S.E. } & \multirow[b]{2}{*}{$\mathrm{P}$-value } & \multirow[b]{2}{*}{ OR } & \multicolumn{2}{|c|}{ 95\% C.I. for OR } \\
\hline & & & & & $\begin{array}{l}\text { Lower } \\
\text { Bound }\end{array}$ & $\begin{array}{l}\text { Upper } \\
\text { Bound }\end{array}$ \\
\hline \multicolumn{7}{|c|}{$\begin{array}{l}\text { Main occupation of household } \\
\text { head }\end{array}$} \\
\hline Agriculture & 1.388 & 0.262 & 0.000 & 4.008 & 2.396 & 6.703 \\
\hline Non-agriculture $\mathbb{R}$ & - & - & - & - & - & - \\
\hline \multicolumn{7}{|c|}{$\begin{array}{l}\text { Educational status of returned } \\
\text { migrant }\end{array}$} \\
\hline Primary level & 0.975 & 0.258 & 0.000 & 2.650 & 1.599 & 4.392 \\
\hline Above primary level $\AA$ & - & - & - & - & - & - \\
\hline \multicolumn{7}{|c|}{$\begin{array}{l}\text { Remittance received at home per } \\
\text { year (in lakh in Rs.) }\end{array}$} \\
\hline Less than 2 Lakhs & 1.816 & 0.508 & 0.000 & 6.149 & $2.27 I$ & $|6.65|$ \\
\hline 2 to 5 Lakhs & 1.168 & 0.330 & 0.000 & 3.216 & 1.685 & 6.137 \\
\hline More than 5 Lakhs $\AA$ & - & - & - & - & - & - \\
\hline \multicolumn{7}{|l|}{ Skills learnt at abroad } \\
\hline No & 1.012 & 0.259 & 0.000 & 2.750 & 1.654 & 4.573 \\
\hline Yes ${ }^{\circledR}$ & - & - & - & - & - & - \\
\hline Constant & -2.436 & 0.397 & 0.000 & 0.087 & & \\
\hline
\end{tabular}

$\mathrm{OR}=$ odds ratio, $\mathbb{R}=$ reference category, S.E. = standard error, C.I. = confidence interval $B=$ coefficient estimate, Negelkerke $R^{2}=0.294$, Hosmer and Lemeshow $p$-value $=0.106$

The Negelkerke Pseudo R square value for the fitted model was appeared to be 0.294 , which implies that $29.4 \%$ of the variation in the response variable is explained by the covariates. Hosmer and Lemeshow test statistic gives $\chi^{2}=10.479$ and $p$-value $=0.106$ indicating that the model can be considered as a good fit to the given data.

\section{DISCUSSION}

Entrepreneurship is the capacity and willingness to develop, organize and manage a business venture with some risk in order to make a profit. Entrepreneurial activities play very important role to diminish unemployment. Nepal has witnessed the emigration of thousands of Nepalese youths for employment. Remittance received by Nepal has been playing significant contribution to the national economy as well as to uplift the economic status of individual family. The present study was initiated to explore the entrepreneurship status of returned migrants and to assess the factor affecting the entrepreneurship status of returned migrants.

The descriptive analysis of the study revealed that there is no such exciting number of entrepreneur among the returned migrants although it shows some degree of expectation of 
better outcome in future. Only 137 (34.9\%) out of 393 returned migrants involved in entrepreneurial activities which shows that most of the returned migrants expenses their earning in non-entrepreneurial sectors which cannot generate employment opportunities for job seekers. Talking about the factors influencing the entrepreneurial behavior of returned migrants, this study has identified four major factors namely, main occupation of household head, educational status of returned migrant, remittance received at home and skills learnt at abroad. Research conducted by McCormick and Wahba (200I) has found that amount of money saved by migrants and length of stay abroad have positive correlation with entrepreneurship status of returned migrants. The present study also obtained one of the same variable that the amount of money received at home country has significant association on entrepreneurship status.

\section{CONCLUSION}

The prime objective of this study was to identify the factors that have significant effect on the entrepreneurial status of returned migrants in Sarawal rural municapility of Parasi district, Nepal. This objective has been achieved, as this study explored that 'main occupation of household head', 'educational status of returned migrants', 'total remittance received at home per year;, and 'skills learnt at abroad' play crucial role for whether the returned migrants become an entrepreneur or not. The major occupation of household head is a significant factor that determine the entrepreneurial behavior of returned migrants as this study found that returned migrants from those household with agriculture as main occupation of household head has higher chances of being non-entrepreneur than those houses whose household head involve in non-agriculture sectors as their main occupation. Educational status of returned migrants is another variable playing important role behind entrepreneurial behavior of returned migrants. The study clearly pointed that the migrants with low educational status have more likelihood to be non-entrepreneur than those who have attained higher educational status. Further, this study also highlighted the importance of skills learnt at abroad to advance the lifestyle of returned migrants. It is found that the skills learnt at abroad has significant contribution to be an entrepreneur than those who did not acquired some skills abroad.

\section{CONFLICT OF INTEREST}

The authors declares that there is no conflict of interest.

\section{ACKNOWLEDGMENTS}

The authors would like to thanks all the local people of the study area who participated voluntarily in this study for their valuable time. We would also like to thank anonymous reviewers for their constructive comments and suggestions to enrich the quality of this paper. 


\section{REFERENCES}

Acharya, C. P., \& Leon-Gonzalez, R. (20/3). The impact of remittance on poverty and inequality: A micro-simulation study for Nepal. Asian Journal of Empirical Research, 3(9), 1061-1080.

Amuedo-Dorantes, C., \& Pozo, S. (2006). Remittance receipt and business ownership in the Dominican Republic. The World Economy, 29(7), 939-956.

Central Bureau of Statistics. (20II). Poverty in Nepal 2010/II. (Central Bureau of Statistics). Kathmandu. www.cbs.gov.np

Chami, R., Fullenkamp, C., \& Jahjah, S. (2005). Are immigrant remittance flows a source of capital for development? IMF Staff papers, 52(I), 55-8I.

De Haas, H. (2010). Migration and development: A theoretical perspective I. International migration review, 44(I), 227-264.

KC, F. B. (2004). Entrepreneurs in Nepal: An Empirical Study. www.epfnepal.com.np

Khadria, B. (2006). India: skilled migration to developed countries, labor migration to the Gulf. Migración y Desarrollo, 7. 4-37.

Lokshin, M., Bontch-Osmolovski, M., \& Glinskaya, E. (2010). Work-Related migration and poverty reduction in Nepal. Review of Development Economics, I4(2), 323-332.

Mahmood, R. A. (1991). Bangladeshi returned migrants from the Middle East: Process, achievement, and adjustment. Migration to the Arab World: Experience of Returning Migrants, 238-289.

McCormick, B., \& Wahba, J. (200I). Overseas work experience, savings and entrepreneurship amongst return migrants to LDCs. Scottish journal of political economy, 48(2), 164-178.

Department of Industry. (n. d.). Industrial Enterprises Act 2016. Retrieved from www.doind.gov.np Nepal Rastra Bank. (2015/16). Financial stability report. (Nepal Rastra Bank Report), Kathmandu, July. Retrieved from www.nrb.org.np

Sperandei, S. (2014). Understanding logistic regression analysis. Biochemia Medica. 24 (I): 12 -8, doi: $10.11613 /$ BM.2014.003

Bolton, B. \& Thompson, J. (2013). Entrepreneurs: talent, temperament and opportunity. Routledge.

Reference to this paper should be made as follows:

Bhusal, M. K., \& Pandey, H. P. (2019). Study of factors affecting the entrepreneurship behavior of returned migrants using binary logistic regression model. Nep. J. Stat., 3, 57-68. 
Nep. J. Stat., Vol. 3, $2019 \quad$ Factors affecting entrepreneurship of returned migrants 